\title{
DERADICALIZATION-BASED ASWAJASI EDUCATION AND MINAGKABAU LOCAL WISDOM IN SYAIKH SULAIMAN'S THOUGHT
}

Muhammad Kosim, Martin Kustati and Duski Samad

Universitas Islam Negeri Imam Bonjol Padang, Indonesia email: muhammadkosim@uinib.ac.id, martinkustati@uinib.ac.id and duskisamad@uinib.ac.id

Abstract: Religious radicalism can lead people to commit acts of violence in the form of physical and non-physical terror in the name of religious teachings. The actions can create a negative stigma about Islam in which has the nature of rahmatan lil 'alamin. One of the main causes for the emergence of religious radicalism is a narrow understanding of the religion. Therefore, religious radicalism needs to be anticipated by the deradicalization of education. The aim of the study is to analyze the thoughts of Sheikh Sulaiman Arrasuli, as one of the influential scholars in Minangkabau, focusing on the deradicalization through education based ASWAJASI and Minangkabau local wisdom. Although the term deradicalization of the education is not found in his books, his thoughts that juxtapose religious education and local wisdom of Minangkabau have relevance in efforts to deradicalize education. In his several writings, Sheikh Sulaiman Arrasuli argued that the deradicalization of education in Minangkabau was carried out by developing the understanding of Ahl al-Sunnah wa alJamā'ah wa Syafi'iyyah which is full of moderate and balanced teachings. In the educational process, teachers are required to have ulama-based competencies, who are ready to be role models and enlighteners for the umara, the importance of collaboration between ulama and umara, prioritizing tafaqquh fi al-din studies in madrasas, strengthening the morals of students who are devout and cultured, and implementing education without violence. The education process is based on religion and local wisdom. 
الملخص: يتسبب التطرف الديني في قيام شخص ما بارتكاب أعمال عنف ضد الإرهاب

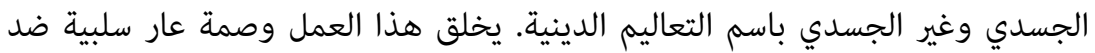

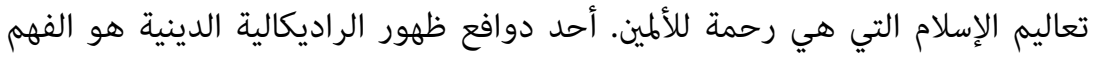

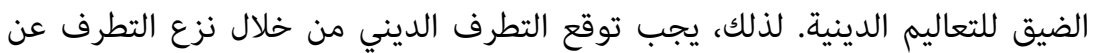

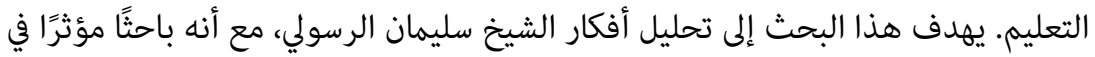

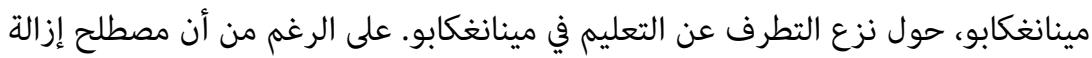

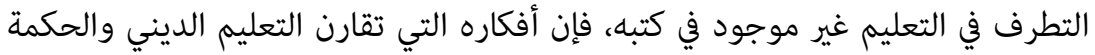

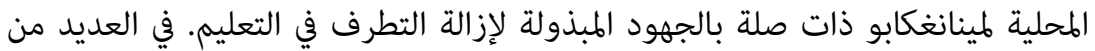

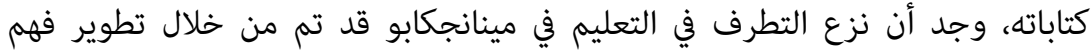

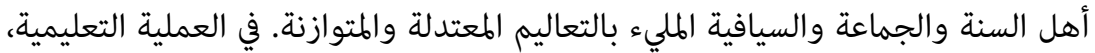

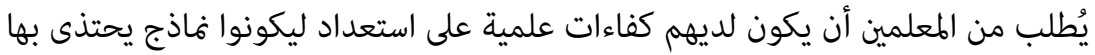

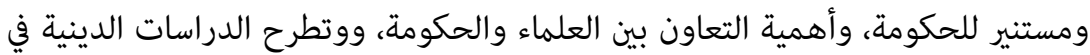

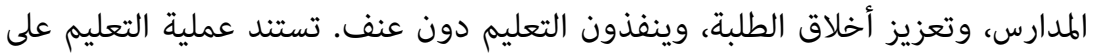

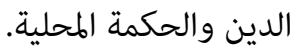

Abstrak: Radikalisme agama mengakibatkan seseorang melakukantindakankekerasanhinggaterorfisikdannonfisikdengan mengatasnamakan ajaran agama. Tindakan ini menimbulkan stigma negative terhadap ajaran Islam yang rahmatan lil 'alamin. Salah satu pemicu munculnya radikalisme adalah pemahaman yang sempit terhadapa ajaran agama. Karena itu radikalisme tperlu diantisipasi dengan melakukan deradikalisasi pendidikan. Artikel ini bertujuan untuk menganalisis pemikiran Syekh Sulaiman Arrasuli, sebagai ulama berpengaruh di Minangkabau, tentang deradikalisasi melalui pendidikan berbasis ASWAJASI dan kearifan lokal Minangkabau. Meskipun istilah deradikalisasi pendidikan tidak ditemukan dalam kitab-kitabnya, akan tetapi pemikirannya yang menyandingkan pendidikan agama dan kearifan lokal Minangkabau, relevan dengan upaya deradikalisasi pendidikan. Dalam beberapa karya tulisnya, ditemukan bahwa deradikalisasi melalui pendidikan di Minangkabau dilakukan dengan mengembangkan paham ahl al-sunnah wa al-jamaah wa syafiyyah yang sarat dengan ajaran moderat (tawasuth) dan seimbang (tawazun). Dalam proses pendidikan, guru dituntut memiliki kompetensi berbasis ulama yang siap menjadi teladan 
dan pencerah umat, pentingnya kolaborasi antara ulama dan umara, mengedepankan kajian tafaqquh fi al-din di madrasahmadrasah, menguatkan akhlak peserta didik yang taat beragama dan berbudaya, serta menerapkan pendidikan tanpa kekerasan. Proses pendidikan tersebut berbasis agama dan kearifan lokal.

Keywords: deradicalization, ASWAJASI-based Education, Sulaiman Arrasuli, local wisdom, Minangkabau.

\section{INTRODUCTION}

The issue of Islamic radicalism has become a transnational discourse that creates a negative stigma against Islam as the religion of rahmatan lil'alamin. ${ }^{1}$ Violence in the name of Islam in the form of physical and non-physical terror is also triggered by a superficial understanding of Islam. Narrow understanding and accompanied by a passionate spirit to make changes quickly triggered the occurrence of religious fundamentalism and radicalism, ${ }^{2}$ which are the origins of terrorism in the name of religion. Religious radicalism can occur through the educational process. It is not surprising that Islamic educational institutions, including Islamic boarding schools, are suspected of teaching fundamentalism and radicalism to students. ${ }^{3}$

Some people even state the stigma of pesantren as the breeding ground for radicalism and terrorism. Mukhibat explained that the "salafi-haraki pesantren" model carries the ideals of purifying Islamic teachings in a more literal, textual, and normative manner in the early $21^{\text {st }}$ century is indicated by some groups with radical religious views and the potential that lead to radicalism. In addition,

'Murad Ismayilov, "Islamic Radicalism That Never Was: Islamic Discourse as an Extension of the Elite's Quest for Legitimation. Azerbaijan in Focus," Journal of Eurasian Studies 10, no. 2 (2019): 183-96. https://doi.org/10.1177/1879366519863167

2 Mifrohatul Musyarrofah, "Deradikalisasi Melalui Pendidikan Karakter Berbasis Khazanah Pesantren," Jurnal MUDARRISUNA: Media Kajian Pendidikan Agama Islam 8, no. 1 (2018): 46-59; Yusuf Qardhawi, Islam Ekstrem: Analisis Dan Pemecahannya, Terj, Alwi AM. Bandung: Mizan, 1991; Muhamad Tisna Nugraha, "Fundamentalisme Pendidikan Agama Di Jejaring Sosial," Al-Tahrir: Jurnal Pemikiran Islam 18, no. 1 (2018): 41-62.

3 Andik Wahyun Muqoyyidin, "Membangun Kesadaran Inklusifmultikultural Untuk Deradikalisasi Pendidikan Islam,” Jurnal Pendidikan Islam 2, no. 1 (2013): 131-51. 
their intellectual and cultural networks have also been labeled as Islamic boarding schools which lead to the potential for radicalism. ${ }^{4}$ Therefore, deradicalization in Islamic educational institutions is important. Deradicalization is the whole effort to neutralize radical ideas through an interdisciplinary approach, e.g., through law, psychology, religion, economics, education, humanity and socioculture for those who are influenced or exposed to radical and/or pro-violence ideology. ${ }^{5}$ Deradicalization of education focuses on efforts to anticipate and neutralize the growth of religious radicalism through education.

There are several studies that offer deradicalization of religion through this education, both conceptual and based on best practices that have been carried out by pesantren. Irwan Masduqi and Mualimul Huda offer deradicalization of Islamic education by developing the characteristics of Islamic boarding schools as educational institutions that promote brotherhood, tolerance, inclusion, humanism and multiculturalism. ${ }^{6}$ Mu'ammar Ramadhan and Rohmat Suprapto conducted research on the deradicalization of religion through inclusive multicultural education, respectively at the al-Hikmah Brebes Islamic boarding school and the Imam Syuhodo Sukoharjo Islamic Boarding School. ${ }^{7}$ On the other hand, Mukhibat emphasized the integration of plurality values in the salafi haraki pesantren curriculum in Indonesia by means of inculturation which includes the stages of translation, assimilation and transformation.

4 Mukhibat Mukhibat, "Deradikalisasi Dan Integrasi Nilai-Nilai Pluralitas Dalam Kurikulum Pesantren Salafi Haraki Di Indonesia," Al-Tahrir: Jurnal Pemikiran Islam 14, no. 1 (2014): 181-204.

5 Isnawan, "Program Deradikalisasi Radikalisme Dan Terorisme Melalui NilaiNilai Luhur Pancasila"; Muqoyyidin, "Membumikan Deradikalisasi Pendidikan Islam Sebagai Respons Antisipatif Radikalisme Di Era Global."

6 Irwan Masduqi, "Deradikalisasi Pendidikan Islam Berbasis Khazanah Pesantren," Jurnal Pendidikan Islam 2, no. 1 (2013): 1-20; Mualimul Huda, "Eksistensi Pesantren Dan Deradikalisasi Pendidikan Islam Di Indonesia," Jurnal Kajian Keislaman Dan Kemasyarakatan 3, no. 1 (2018): 91.

7 Muammar Ramadhan, "Deradikalisasi Agama Melalui Pendidikan Multikultural Dan Inklusivisme (Studi Pada Pesantren Al-Hikmah Benda Sirampog Brebes)," Jurnal SMART (Studi Masyarakat, Religi, Dan Tradisi) 1, no. 2 (2015); Rohmat Suprapto, "Deradikalisasi Agama Melalui Pendidikan Multikultural-Inklusiv (Studi Pada Pesantren Imam Syuhodo Sukoharjo)," Profetika: Jurnal Studi Islam 15, no. 02 (2016): 246-60. 
The inculturation process is realized on the aspects of the material, method and contextual evaluation. ${ }^{8}$

This article describes the deradicalization through education that occurred in Minangkabau by examining the thoughts of Sheikh Sulaiman Arrasuli and his practice at the educational institution he founded, Madrasah Tarbiyah Islamiyah (MTI) Canduang since 1928. ${ }^{9}$ Shaykh Sulaiman Arrasuli, also known as Inyiak Canduang, is a charismatic scholar from Canduang, Agam Regency, West Sumatra, who went Mecca and studied from Sheikh Ahmad Khatib al-Minangkabauwi. He was a contemporary of KH. Ahmad Dahlan, founder of Muhammadiyah, and Hasyim Asy'ari, founder of Nahdlatul Ulama. Even Shaykh Sulaiman also founded the Tarbiyah Islamiyah Association (PERTI) as the largest Islamic organization in West Sumatra and on a national scale to date. In 1945, PERTI became an Islamic political party and participated in the general elections in 1955. Shaykh Sulaiman was elected as a member of the Constituent Assembly and was entrusted with being the leader of the first constituent assembly on 10 November 1956 in Bandung. ${ }^{10}$

This organization originated from Madrasah Tarbiyah Islamiyah (MTI) which he founded in 1928. MTI is a renewal of the surau educational institution from a halaqah system to a madrasa with a classical learning system. One of the reasons for the renewal of this educational institution was in response to the emergence of Dutch schools with a classical system that was beginning to be accepted by the community. In addition, youth scholars whose style of thought were more progressive, reformer, ${ }^{11}$ and in line with the thoughts of reformer Sheikh Muhammad Abduh had also made changes from surau to madrasah which became known as Madrasah Sumatera Thawalib. ${ }^{12}$

${ }^{8}$ Mukhibat, "Deradikalisasi Dan Integrasi Nilai-Nilai Pluralitas Dalam Kurikulum Pesantren Salafi Haraki Di Indonesia."

9 Alaiddin Koto; Mafri Umar; Abdul Halim, Sejarah Perjuangan Persatuan Tarbiyah Islamiyah Di Pentas Nasional (Jakarta: Tarbuyah Press, 2006). 61.

${ }^{10}$ Hasril Chaniago, 101 Orang Minang Di Pentas Sejarah (Padang: Yayasan Citra Budaya Indonesia, 2010).

${ }^{11}$ Mansoureh Ebrahimi Sarwan and Kamaruzaman Yusoff, “Al-Imam Magazine (1906-1908): The Study of Kaum Muda's Thought on Islamic Education Renewal in Southeast Asia," Journal of Critical Reviews 7, no. 11 (2020): 499-503.

${ }^{12}$ Karel A. Steenbrink, Pesantren, Madrasah, Sekolah: Pendidikan Islam Dalam Kurun Moderen, (Jakarta: LP3ES, 1994), 64. 
Shaykh Sulaiman is known as an old cleric whose traditional way of thinking about religion maintains the I'tiqad Ahl al-Sunnah wa alJamā'ah with the Syafi'i sect, just like the religious understanding that developed at the beginning of the emergence of Islam in the archipelago. His role is not only as a scholar, $d a^{\prime} i$ and educator in the MTI that he founded, but also as a leader, politician, customary expert, and also a productive writer. One of his many works that has been studied related to education that juxtaposes Islam and adat is "Pedoman Hidoep di Alam Minangkabau (Nasihat Siti Boediman) Menoeroet Garisan Adat dan Sjara' - Living Guidelines in Minangkabau (Siti Boediman's Advice) According to Adat and Syara" (1939). ${ }^{13}$

Thus, analyzing the thoughts of Sheikh Sulaiman Arrasuli needs to be done because it is inseparable from the experience and knowledge he has both in the fields of Minangkabau religion and culture. There are several studies related to Sheikh Sulaiman Arrasuli, e.g., the thesis researces conducted by Zulkifli ${ }^{14}$ and Rina Amrin. ${ }^{15}$ In the form of doctoral research, there is a thesis written by Muhammad Kosim and Yulizal Yunus. ${ }^{16}$ Kosim also wrote an article about Sheikh Sulaiman as a figure of cultural education, ${ }^{17}$ however, this study does not discuss deradicalisation. Shaykh Sulaiman Arrasuli did not speak specifically about the deradicalization, but if read in full, his writings found ideas that were relevant to the deradicalization through education efforts which were expected to be a source of inspiration for the application of deradicalization in a modern context. Among the thoughts of Sheikh Sulaiman Arrasuli, the most prominent thought in applying the strategy of deradicalisation is the application of ASWAJASI ( $A h l$ al-Sunnah wa al-Jamā'ah wa Syafi'iiyah) education as a theological basis of moderate and gentle character. In addition, Sheikh Sulaiman

${ }^{13}$ Muhammad Kosim, "Syekh Sulaiman Al-Rasuli Tokoh Pendidikan Islam Bercorak Kultural," Turast: Jurnal Penelitian Dan Pengabdian 3, no. 1 (2015): 23-41.

${ }^{14}$ Zulkifli, "Syekh Sulaiman Al-Rasuli; Upaya Pembaharuan Pendidikan Islam Di Minangkabau (Tesis)" (Pascasarjana IAIN Imam Bonjol Padang, 2010).

${ }^{15}$ Rina Amrin, "Pemikiran Hukum Islam Syekh Sulaiman Al-Rasuli Dan Syekh Ibrahim Musa (Tesis)” (Pascasarjana IAIN Imam Bonjol Padang, 2011).

${ }^{16}$ Yulizal Yunus, "Aspek-Aspek Pendidikan Islam Dalam Sastra Ulama Minangkabau; Studi Syair Syekh Sulaiman Al-Rasuli” Disertasi (Pascasarjana UIN Imam Bonjol Padang, 2018).

${ }^{17}$ Kosim, "Syekh Sulaiman Al-Rasuli Tokoh Pendidikan Islam Bercorak Kultural." 
Arrasuli also stressed the importance of the involvement of customs and culture in shaping one's personality. Minangkabau as the birthplace and place of activity of Sheikh Sulaiman Arrasuli is also known to have cultural values derived from religion, as reflected in the philosophy of life of the Minangkabau people: Adat Basandi Syarak, Syarak Basandi Kitabullah. Examining the thoughts of Sheikh Sulaiman Arrasuli related to ASWAJASI-based education and local Minangkabau wisdom as an effort to deradicalize, it is interesting to do. Especially the concept Moreover, the concept of deradicalization is not only found in his works conceptually, but also in the Madrasah Tarbiyah Islamiah, which has developed in Minangkabau until today. For thos reason, the aim of this article is to examine the thoughts of Syekh Sulaiman Arrasuli regarding deradicalization through education in Minangkabau based on ASWAJASI based education and Minangkabau local wisdom.

Deradicalization of education is not only found in his conceptual works, but also in the Islamic Tarbiyah Madrasah, which has developed a lot in Minangkabau until now. Therefore, this article was written to examine the thoughts of Sheikh Sulaiman Arrasuli regarding the deradicalization of education in Minangkabau through several books he wrote. This research is a research library which is carried out through data collection or scientific writing in order to solve the problem, by interpreting and looking for the meaning of written texts. ${ }^{18}$ Library research directs research towards studying and tracing the ideas and repertoire of thoughts in the works of Shaykh Sulaiman Arrasuli personally and the works of others who examine the profile and thoughts of Sheikh Sulaiman Arrasuli. The approach used in understanding and interpreting literature and texts is the hermeneutic approach. This is conducted in understanding the meaning of the texts in order to avoid distortion of messages or information between the writers and the readers. ${ }^{19}$

The content analysis method is applied in processing and analyzing all literature and text data, ${ }^{20}$ to measure the level of

${ }^{18}$ Bagong Suyanto, Metode Penelitian Sosial: Berbagai Alternatif Pendekatan (Prenada Media, 2015), 186.

${ }^{19}$ Imam Suprayogo and Tobroni, Metodologi Penelitian Sosial-Agama (Remaja Rosdakarya, 2001), 73-75.

${ }^{20}$ Suprayogo and Tobroni, 134-136. 
accuracy and the process of drawing conclusions on messages. There are three steps taken at this stage: descriptive, critical content analysis, and correlative. ${ }^{21}$ The first step was taken by collecting data from references to scientific studies of Syekh Sulaiman Arrasuli on education then categorizing them and describing them in the study of deradicalization of education. Second, critical content activities, after describing the concepts of Sheikh Sulaiman Arrasuli's thoughts, then analyzed using an analysis of inductive, deductive, and interactive analytical thinking patterns to find his thoughts on deradicalization through ASWAJASI-based education and local wisdom in Minangkabau; and third, correlative by providing interpretation and meaning of the results of the analysis and correlating existing theories with the aim of drawing conclusions. From this interpretive conclusion, ideas and ideas about the object of research are built.

The data processing process in this study is grouped into three stages: 1) collecting data from references to scientific studies of Shaykh Sulaiman Arrasuli on education then classifying them and describing them in the study of educational deradicalisation; 2) data analysis was carried out after describing the concepts of Shaykh Sulaiman Arrasuli's thoughts which were then analyzed using inductive, deductive and interactive analytical thinking patterns to find his thoughts on the deradicalization of education in Minangkabau; and 3) interpreting and interpreting the results of the analysis in order to draw conclusions. Ideas about the object of research are obtained through interpretive conclusions.

\section{DERADICALIZATION BASED ON ISLAMIC EDUCATION}

Radicalism in the name of religion has damaged the sanctity of religion. Generally, religious radicalism arises from a closed (fanatical) and textual (rigid) understanding of religion, so that they feel that only their group is the most correct. This creates an understanding that makes other groups considered infidels and entitled to be fought with violence. Radicalism as a flow or understanding emerges through a process of recognition, cultivation, appreciation and strengthening. This process is known as radicalization. If radicalization goes well,

${ }^{21}$ Klans Purippendolf, Analisis Isi: Pengantar Teori Dan Metodologi (Jakarta: Rajawali Press, 1991), 15. 
it will become a cult sect and become radical. ${ }^{22}$ To break the chain of radicalism which is now increasingly dangerous in Indonesia, especially radicalism and terrorism in the name of religion in understanding the texts of the Qur'an, especially regarding the context of jihad, the alternative solution offered is to carry out deradicalization based on Islamic education. ${ }^{23}$

In English, the origin of the word "deradicalization" is radical. Deradicalization means: opposite, reverse, remove, reduce, get off (reverse or reverse). The meaning of the word deradicalization is a process or effort to eliminate radicalism. Deradicalization is all efforts to neutralize radical ideas through an interdisciplinary approach, e.g., through law, psychology, religion, and socio-culture for those who are influenced or exposed by radical and/or pro-violence ideas, in this case including prisoners (convicts), former convicts, and radical militant individuals who have been involved, their families, sympathizers, and the general public. ${ }^{24}$ Deradicalization is all the efforts made to release ideologies or understandings from within the perpetrators of violence or stop the process of spreading ideology more broadly, this effort is called deideologization. ${ }^{25}$

Deradicalization can be started directly from the elements and roots of radicalism which are intended as preventive deradicalization and preservative deradicalization of moderate Islam, and in addition, deradicalization can also be done after someone becomes radical (curative deradicalization). ${ }^{26}$ Hikam stated that there are two meanings of deradicalization: disengangement and deideoligization. Disengagement is directed at changes in behavior such as leaving someone from the group or changing the rules of life of a person towards the group. Deideologization, on the other hand, is directed at eliminating ideological understanding of Islamic political doctrine

${ }^{22}$ Karwadi Karwadi, "Deradikalisasi Pemahaman Ajaran Islam," Al-Tahrir: Jurnal Pemikiran Islam 14, no. 1 (2014): 139-56.

${ }^{23}$ Khairul Saleh and Muhammad Arbain, Deradikalisasi Di Perguruan Tinggi: Strategi Menangkal Radikalisme Melalui Pendidikan Islam (Yogyakarta: Ar-Ruzz Media, 2019), 18-19.

${ }^{24}$ Mukhibat Mukhibat, "Re-Edukasi Dan Re-Motivasi Terhadap Pelaku Radikalisme Dan Terorisme: Membangun Kesadaran Keagamaan Yang Inklusif Dan Humanis Di Indonesia," SOSIOHUMANIKA 7, no. 1 (2014).

${ }^{25}$ Saleh and Arbain, "Deradikalisasi Di Perguruan Tinggi: Strategi Menangkal Radikalisme Melalui Pendidikan Islam."

${ }^{26}$ Saleh and Arbain, 114. 
and making Islam as noble values that sow peace. Deideologization is an attempt to reduce, revise, or replace someone's ideology for their

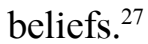

Deradicalization implemented by the government through the National Counterterrorism Agency (Badan National Penanggulangan Terorisme $-B N P T$ ) has set two targets, i.e., terrorist inmates and the general public with two main programs, i.e., the anti-radicalization program and the deradicalization program. The anti-radicalism program is carried out in the form of socialization through seminars, FGDs, or workshops on the religious education curriculum as well as the establishment of the Counter-Terrorism Coordination Forum (Forum Koordinasi Penanggulangan Terorisme-FKPT) in the regions. BNPT deradicalisation program is aimed at terrorist convicts and former terrorist convicts who have committed violent and criminal acts with four approaches: rehabilitation, re-education, resocialization, and reintegration. ${ }^{28}$ BNPT also implements the National Deradicalization Movement with six program objectives, namely empowering places of worship, increasing the capacity of religious education institutions (pesantren), increasing the role of general and vocational secondary education institutions, increasing the role of higher education, empowering media literacy, and increasing the role of mass organizations. ${ }^{29}$

Thus, deradicalization implemented in education is relevant with the government's efforts mentioned above. Optimizing the role and function of Islamic education institutions as a transfer of Islamic knowledge and planting noble values derived from the Qur'an and Hadith is a deterrent in reducing various forms of radicalism and terrorism. If Islamic education is maximized properly, radicalism and terrorism can be prevented from an early age through the basis of Islamic education. This is what Sheikh Sulaiman Arrasuli did. As a charismatic scholar in Minangkabau, he has developed a moderate and accommodating model of Islamic education with local wisdom. Deradicalization developed by Syekh Sulaiman Arrasuli is based on

${ }^{27}$ Muhammad A. S. Hikam, Deradikalisasi: Peran Masyarakat Sipil Indonesia Membendung Radikalisme (Penerbit Buku Kompas, 2016), viii.

${ }^{28}$ Jely Agri Famela, "Pro Dan Kontra Pelaksanaan Program Deradikalisasi Badan Nasional Penanggulangan Teroris (BNPT)," FISIP UI, 2013.

${ }^{29} \mathrm{http}$ ://www.politik.lipi.go.id/kolom/kolom-1/tinjauan-buku/1230-tinjauanbuku-membumikan-deradikalisasi. 
ASWAJASI education and Minangkabau local wisdom education which harmonizes Minangkabau religion and culture.

\section{DERADICALIZATION IN THE ASWAJASI-BASED EDUCATION}

ASWAJASI stands for Ahl al-Sunnah wa al-Jamā'ah wa Syaf'iiyah. Shaykh Sulaiman Arrasuli together with the ulama of the Elderly in Minangkabau who are also members of the Islamic Tarbiyah Association. At the beginning of the twentieth century in Minangkabau there were two groups of scholars, namely the ulama of the Old and the ulama of the youth. Ulama of the Tua is the term for ulama from traditional groups, by maintaining the religious understanding adhered to by Muslims in Minangkabau since the early entry of Islam to this area. Youth scholars, on the other hand, did not rely on a particular school of thought in matters of fiqh. They were more progressive and much influenced by the thoughts of Islamic reformers in the $9^{\text {th }}$ century, such as Jamaluddin al-Afghani and Shaykh Muhammad Abduh.

I'tiqad Ahl al-Sunnah wa al-Jamā'ah which is defended by the elderly scholars refers to the teachings of Imam Abu Hasan alAsy'ari, the founder of the Asy'ariyah group and Imam Abu Mansur al-Maturidiyah. Whereas in matters of sharia and worship, stick to the Imam Syafi'i mazhab. ${ }^{30}$ Although not all of them adhere to and practice the teachings of the tarekat, in principle they recognize the truth of the tarekat which is considered mu'tabarah, and therefore they feel compelled to defend it. ${ }^{31}$ Here, the most developed tarekat are the Naqsyabandiyah and Syathāriyah orders, in addition to other mu'tabarah tarekat. The mu'tabarah tarekat is a tarekat that is recognized by the Islamic community and this tarekat does not deviate from Islamic teachings, both its monotheism and the syari'at it adheres to. The mu'tabarah tarekat departed from the Sunni tasawwuf within the Ahl al-Sunnah wa al-Jamā'ah environment. ${ }^{32}$

${ }^{30}$ Siradjuddin Abbas, Sejarah Dan Keagungan Madzhab Syafi i (Jakarta: Pustaka Tarbiyah Baru, 2010).

${ }^{31}$ Alaiddin Koto, Persatuan Tarbiyah Islamiyah: Sejarah, Paham Keagamaan, Dan Pemikiran Politik 1945-1970 (Jakarta: RajaGrafindo Persada, 2012).

${ }^{32}$ Syamsul Bahri Khatib, Tarekat Abd Al-Rauf Singkel Dalam Tanbih Al-Masyi (Padang: Hayfa Press, 2012), 12. 
Shaykh Sulaiman Arrasuli's work entitled al-Aqwālu alMardhiyah proves that he is a scholar who adheres to I'tiqad Ahl al-Sunnah wa al-Jamā 'ah. The book contains 20 characteristics with a brief explanation of I'tiqad Ahl al-Sunnah wa al-Jamà'ah and is a basic reference for his students and is still surviving in the madrasas he founded and in several other Islamic Tarbiyah Madrasas which still survive to this day. ${ }^{33}$ In terms of syari'at, he is also known as a figure who has mastered the science of fiqh of mazhab Syafi ' $i{ }^{34}$

In the field of Sufism, Shaykh Sulaiman al-Rasuli is a Naqsyabandiyah practitioner. Although his teacher, Shaykh Ahmad Khatib al-Minangkabawi, was one of the scholars who challenged the practice of the tarekat, but after returning from Mecca, Shaykh Sulaiman al-Rasuli, he went to Batu Hampar under the guidance of his previous guru, Shaykh Muhammad Arsyad. Sanusi Latif mentions that Shaykh Sulaiman al-Rasuli obtained a diploma from Shaykh Arsyad and became a tarekat teacher and led suluk in Canduang. ${ }^{35}$ According to Martin van Bruinessen, on the other hand, Shaykh Sulaiman al-Rasuli was a Naqsyabandi who was the caliph of Shaykh Yahya al-Khalidi, who was appointed by Sa' ad Mungka. ${ }^{36}$

Based on the description above, the religious understanding of Shaykh Sulaiman al-Rasuli is Ahl Sunnah wa al-Jamā'ah and on matters of sharia or worship Shaykh Sulaiman al-Rasuli follows the Imam Syafi'i school of thought. This made him close to the Minangkabau people who at that time, in general, had the same understanding. Despite the emergence of movements from among young people, as mentioned above, Shaykh Sulaiman al-Rasuli did not show a frontal "hostility" to them. Shaykh Sulaiman al-Rasuli is one of the scholars of the elderly who have moderate views on the

${ }^{33}$ Muhammad Kosim, "Gagasan Syekh Sulaiman Al-Rasuli Tentang Pendidikan Islam Dan Penerapannya Pada Madrasah Tarbiyah Islamiyah Di Sumatera Barat", Dissertation Pascasarjana IAIN Imam Bonjol Padang (Padang, 2013).

${ }^{34}$ Abbas, Sejarah Dan Keagungan Madzhab Syafi'i.

${ }^{35}$ Sanusi Latif, “Gerakan Kaum Tua Di Minangkabau”, Disertasi, (IAIN Syarif Hidayatullah Jakarta, 1988).

${ }^{36}$ Martin van Bruinessen, Tarekat Naqsyabandiyah Di Indonesia (Bandung: Mizan, 1992), 130-131. 
thoughts of young people. This attitude has made his name respected and respected by many circles, both those who agree with him or not. ${ }^{37}$

ASWAJASI's religious understanding became the basis of education developed by Shaykh Sulaiman at Madrasah Tarbiyah Islamiyah Canduang and other MTIs. This is also why the diplomas of students who graduated from the Canduang Tarbiyah Islamiyah Madrasah and in several other MTIs were signed by Shaykh Sulaiman al-Rasuli himself. In the diploma he advised his students to stick to I'tiqad Ahl al-Sunnah wa al-Jamā 'ah. Meanwhile, in matters of sharia and worship, it refers to the four schools of thought. However, when determining fatwas and laws, one must refer to the Imam Syafi' $i$ school of thought..$^{38}$

The development of ASWAJASI's religious understanding needs to be done as the main basis for deradicalization of education. I'tiqad Ahl al-Sunnah wa al-Jamā'ah contains an understanding of Islam that is tolerant, inclusive and moderate. ${ }^{39}$ As Asep Awaluddin emphasized, Asep Awaluddin and Maturidiyah understandings emerged as moderate theological schools that tried to combine textual and rational arguments (naqli and aqli) at the same time. ${ }^{40}$ Muhammad Idrus Ramli also explained that I'tiqad Ahl al-Sunnah wa al-Jamā'ah theology took a moderate (tawasuth) and balanced (tawazun) attitude, not as extreme as Mu'tazilah which prioritized reason over syara, nor as extreme as Hasyawiyah and Zhahiriyah which embraced syara domination by ignoring reason. M. Quraish Shihab also argued that Abu Hasan al-Asy'ari was a central figure in moderate Islam. This is evident when there is an argument between Jabariah and Qadariah about whether human action comes from God or not (theological problem), Abu Hasan al-Asy'ari intervenes with

${ }^{37}$ Kosim, Gagasan Syekh Sulaiman Al-Rasuli Tentang Pendidikan Islam Dan Penerapannya Pada Madrasah Tarbiyah Islamiyah Di Sumatera Barat.

${ }^{38}$ Muhammad Kosim, "Tradisi Madrasah Tarbiyah Islamiyah Di Sumatera Barat" IV, no. 1 (2013): 21-45.

${ }^{39}$ Mualimin Mochammad Sahid, Ahmad Nur Jihadi, and Setiyawan Gunardi, "Moderate Islam As A Solution To Pluralism In The Islamic World: The Experience Of Indonesia," Al-Shajarah: Journal of the International Institute of Islamic Thought and Civilization (ISTAC), 2019, 1-24.

${ }^{40}$ Asep Awaluddin, "Urgensi Ahlu Sunnah Wal Jama'ah dan Pendidikan Kebangsaan (Tinjauan Atas Qonun Assasy Ahlu Sunnah Wal Jama'ah Karya Rois Akbar Nahdlatul Ulama KH. Hasyim Asy'ari)," Muslim Heritage 5, no. 2 (2020): 344. 
the offer of al-Kasb (endeavor). ${ }^{41}$ Moderate Islamic understanding needs to be developed as an antidote to religious radicalism. ${ }^{42}$

The understanding of Ahl al-Sunnah wa al-Jamā'ah was also developed by Nahdlatul Ulama in its educational institutions in the form of local content subjects, ASWAJA. The results showed that Madrasah Aliyah Ma'arif NU Blitar and SMA Diponegoro Tulungagung are examples of schools that have succeeded in developing ASWAJA lessons and instilling the noble values of ASWAJA in their students, so that they are able to fortify themselves from the influence of radical groups..$^{43}$

Shaykh Sulaiman Arrasuli also chose the Syafi'i School in matters of fiqh. According to him, in the past, there were no fiqh books circulating in Minangkabau and its surroundings except for the Minhā $j$ al-Thālibīn book by Imam Nawawi which had the Shafi'i sect. It is through this book that the Minangkabau people know Islamic laws related to fiqh, such as ways of worship, the law of buying and selling, marriage, thalaq, and so on. Although there was already a Quran and its commentary, teachers in general at that time did not see the laws in the Quran but simply referred to the book of Minhāj al-Thā $l i b \bar{i} n .{ }^{44}$

Imam Syafi'i's own mindset is considered more tolerant, as a "middle way" between the more rational Hanafi school (ahl al-ra'yi) and the traditional Maliki school (ahl al-hadith).$^{45}$ The methodology of legal istimbath which was initiated by Imam Syafi'i which later became known as the science of Ushul Fiqh is Imam Syafi'i's moderate thought in understanding the verses of the Qur'an and hadith; moderate in the sense of the middle between aqli and naqli.

${ }^{41}$ M Quraish Shihab, Islam Yang Saya Pahami: Keragaman Itu Rahmat (Lentera Hati Group, 2018), 126.

${ }^{42}$ Mahmudi Mahmudi, "Islam Moderat Sebagai Penangkal Radikalisme," in Proceedings of Annual Conference for Muslim Scholars, 2018, 82-91.

${ }^{43}$ Didin Wahyudin, "Pendidikan Aswaja Sebagai Upaya Menangkal Radikalisme," Dinamika Penelitian: Media Komunikasi Penelitian Sosial Keagamaan 17, no. 2 (2017): 291-314.

${ }^{44}$ Syekh Sulaiman Arrasuli, "Keadaan Minangkabau Dahulu Dan Sekarang," Majalah Al-Mizan (Maninjau, 1938).

${ }^{45}$ Hasan Zaini; Muhammad Kosim; Aldomi, Prinsip Dan Jati Diri Persatuan Tarbiyah Islamiyah (Padang: Jasa Surya, 2015). 
However, Imam Syafi'i respects people with different opinions. ${ }^{46}$ The Shafii school is considered very suitable for the Indonesian Muslim community, this school is a moderate school and can adapt to the socio-historical nature of the Indonesian Muslim community so that the existence of the use of the Shafii school in Indonesia continues to this day. ${ }^{47}$

Azyumardi Azra also mentioned that the identity of Indonesian Islam wasathiyah has its own orthodoxy which consists of three aspects; kalam (theology) Asy'ariyah-Jabariyah, fiqh mazhab Syafi'i and tasawu al-Ghazali. These three aspects of orthodoxy were formed in the archipelago - especially since the 17-18 century AD - due to the contribution of several major authoritative scholars such as' Abd al-Ra'uf al-Singkili, Ar-Raniry, Muhammad Yusuf al-Makassari, Muhammad Arsyad al-Banjari, Abd al-Samad al-Palimbani and others. Indonesian Islamic orthodoxy Wasathiyah has become a great tradition that includes various local traditions practiced by various ethnic groups and Muslim communities in Indonesia. ${ }^{48}$

Although Shaykh Sulaiman Arrasuli practiced the Naqsyabandiyah order, this tarekat was not obligatory for his students at MTI Canduang. For him, Sufism should be given to students who already have a strong understanding of Sharia. He wrote "The wisdom and use of keeping a part of knowledge secret from some humans is that they do not deserve to receive the secret knowledge, like children who have not yet grown teeth should not be given solid food." 49 However, Shaykh Sulaiman's involvement in practicing the Naqsyabandiyah tarekat confirms that he is an influential figure in Minangkabau who has spread an attitude of religious moderation because the real practice of the tarekat is practicing religious moderation in daily life. ${ }^{50}$

${ }^{46}$ Ahmad Sanusi, "Pemikiran Ushul Fiqh Imam Syafi'i," Syakhsia: Jurnal Hukum Perdata Islam 19, no. 2 (2018): 223-44.

${ }^{47}$ Anny Nailatur Rohmah and Ashif Az Zafi, "Jejak Eksistensi Mazhab Syafii Di Indonesia," Tamaddun: Jurnal Sejarah Dan Kebudayaan Islam 8, no. 1 (2020).

${ }^{48}$ Azyumardi Azra, “Kembali Ke Jati Diri (2)," Republika, November 2016, https://republika.co.id/berita/kolom/resonansi/16/11/23/oh3nmo319-kembali-ke-jatidiri-2.

${ }^{49}$ Syekh Sulaiman Arrasuli, Tabligh Al-Amānah (Bukittinggi: t.p., 1954).

${ }^{50}$ Feriyanto Feriyanto, "Tarekat Dan Moderasi Beragama," Tatar Pasundan: Jurnal Diklat Keagamaan 14, no. 2 (2020): 158-72. 
Thus, ASWAJASI's religious understanding is an understanding of moderate Islam (wasathiyah) which has a contribution to counteracting radicalism. Eka Prasetiawati wrote that moderate character (tawasuth) is the most prominent characteristic of $\mathrm{Ahl}$ alSunah wa al-Jamā'ah, in addition to i'tidal (being fair), tawazun (being balanced), and tasamuh (being tolerant), so that he rejects all forms of extreme actions and thoughts (taharuf) that can give birth to deviations and deviations from Islamic teachings. In religious thought, a balance (middle way) is also developed between the use of revelation (naqliyah) and ratio ('aqliyah) so that it is possible to accommodate changes in society as long as it does not oppose dogmatic doctrines. Ahl al-Sunah wa al-Jamā'ah also have more tolerant attitudes towards tradition than those of other Islamic groups. $^{51}$

Therefore, implementing ASWAJASI's religious understanding is something that needs to be done in the deradicalization through education as developed by Shaykh Sulaiman Arrasuli both in his written works and in his educational practices at Madrasah Tarbiyah Islamiyah at MTI Canduang and other MTIs. The deradicalization based ASWAJASI education will produce graduates of moderate, tolerant educational institutions while maintaining a critical culture but obeying established Islamic doctrines. As mentioned by Masnur Alam, "the moderate education within Islamic education institutions can prevent or counter radicalism, extreme behaviour, and conflict. ${ }^{52}$

\section{DERADICALIZATION OF EDUCATION BASED ON LOCAL WISDOM}

Shaykh Sulaiman Arrasuli is an influential scholar in Minangkabau. In addition to having in-depth knowledge of Islam, he also mastered knowledge related to Minangkabau customs and culture. This unique ability is evident in his writings that juxtapose religion and custom, while still making religion the foundation and main axis. Gusti Asnan wrote "In the 1950s, Shaykh Sulaiman al-Rasuli was very enthusiastic

${ }^{51}$ Eka Prasetiawati, "Menanamkan Islam Moderat Untuk Menanggulangi Radikalisme Di Indonesia," Fikri: Jurnal Kajian Agama, Sosial Dan Budaya 2, no. 2 (2017): 523-70.

${ }^{52}$ Masnur Alam, "A Collaborative Action in the Implementation of Moderate Islamic Education to Counter Radicalism," International Journal of Innovation, Creativity and Change 11 (2020). 
in disseminating the idea of integrating adat and Syarak. The expression of the Adat Basandi Syarak, Syarak Basandi Kitabullah which is currently popular is the result of the 'socialization' of this great scholar on various occasions throughout the 1950s."53 The saying Syarak Mangato, Adaik Mamakai (Syara said, Adat applied) is also presented in his work in the form of notification entitled "Sari Pati Sumpah Satie Bukit Marapalam - The Essence of the Bukit Marapalam Divine Oath."

According to him, religion and culture need to be united while still making religion the main basis. He wrote in "Mari Bersatu dengan Adat dan Syara" (Let's Unite with Adat and Syarak): Let all of us (both alim ulama, ninik mamak and cadiak pandai) admit that true Adat and Islam are inseparable and both must unite and will be better if we add modern knowledge within and them into "tungku tigo sajarangan" (the three-stone furnace)." 54 Shaykh Sulaiman Arrasuli is also known as a scholar who maintains the relationship between adat and syara. He is one of the scholars who are worried about the life of the Minangkabau people which is threatened by the separation of Adat and Islam. That is why, he wrote an edict entitled "Sari Pati Satie Bukit Marapalam" on June 7, 1964 AD or 26 Muharam 1384 H in Canduang. At the end of the edict, he emphasized:

"Demikianlah hambo wasiatkan untuk dipedomani oleh anak cucu hambo kemudian hari di Canduang khususnya dan di Minangkabau umumnya, karena sudah terdengar orang-orang yang hendak mencoba memisahkan adat dan agama di Minangkabau"

(Thus, I will testify that this will serve as a guideline for our future children and grandchildren in Canduang in particular and in Minangkabau in general, because there are already people who want to try to separate Adat and Islam in Minangkabau)." ${ }^{55}$

${ }^{53}$ Gusti Asnan, Kamus Sejarah Minangkabau (Padang: Pusat Pengkajian Islam dan Minangkabau (PPIM), 2003, 2003), 308.

${ }^{54}$ Syekh Sulaiman Arrasuli, "Mari Bersatu Dengan Adat Dan Syarak (Harian Haluan) Q," April 1951.

${ }^{55}$ Kosim, Gagasan Syekh Sulaiman Al-Rasuli Tentang Pendidikan Islam Dan Penerapannya Pada Madrasah Tarbiyah Islamiyah Di Sumatera Barat, 247. 
In the context of deradicalization of education, religious education and local wisdom are important. ${ }^{56}$ The style of religious education that is applied is the understanding of Ahl al-Sunnah wa al-Jamā'ah wa Syafi'iyyah, as explained above. Meanwhile, the local wisdom referred to is the Minangkabau culture. The custom of Basandi Syara, Syara Basandi Kitabullah is the cultural foundation and life philosophy of the Minangkabau people. Islam is the glue that makes Adat unite and compound with the teachings of Islam as a religion of rahmatan lil 'alamin. ${ }^{57}$ Minangkabau customs and culture are also known to uphold democratic values, openness and equality (egalitarianism). This is reflected in the saying "duduak samo randah, tagak samo tinggi" (sitting at the same low, standing at the equal height). The values of equality in Minangkabau culture are not based on the philosophy of extreme liberalism. But Minangkabau culture upholds ethics in social relations. Respect for the rights of others is also reflected in the expression "nan ketek dilindungi, nan tuo dihormati, nan samo gadang dipatenggangkan" (protect the younger, respect the elders respected, tolerate the same age).$^{58}$ These cultural values are very relevant to efforts to realize deradicalization.

In the books written by Shaykh Sulaiman Arrasuli, there are several thoughts that are relevant to the efforts to deradicalize education based on religion and Minangkabau culture. First, competent educators of solar scholars. Shaykh Sulaiman al-Rasuli understands the role of teachers as scholars who are not only tasked with educating their students in madrassas, but also as people who have profound knowledge, as protectors and guides for society. $\mathrm{He}$ calls the ideal figure of the ulama with the term "ulama matahari" (sun scholar) which means "suluah bendang di nagari, camin taruih dalam suku..." (as a place to ask for people in the nagari, as a reflection or

${ }^{56}$ Sulistiyono Susilo and Reza Pahlevi Dalimunthe, "Moderate Southeast Asian Islamic Education as a Parent Culture in Deradicalization: Urgencies, Strategies, and Challenges," Religions 10, no. 1 (2019): 45. https://doi.org/10.3390/rel10010045

${ }^{57}$ Farhan Muin Dt. Bagindo, "Pokok-Pokok Ajaran Adat Minangkabau, Adat Basandi Syarak, Syarak Basandi Kitabullah Beserta Penjelasannya Dan Berlaku Untuk Seluruh Wilayah Minangkabau," in Mambangkik Batang Tarandam Minangkabau Di Tapi Jurang, ed. AL Bazar M Arif (Jakarta: YPMUI, 2013).

${ }^{58}$ Miswar Munir, "Nilai-Nilai Pendidikan Dalam Petatah Petitih Adat Minangkabau (Alternatif Membangun Pendidikan Berkarakter)," Al Hurriyah: Jurnal Hukum Islam 14, no. 1 (2018): 95-104. 
role model for society ...). ${ }^{59}$ Sefriyono and Mukhibat in their research also found that the existence of ulama (mufti nagari) who elaborated on tarekat teachings, customs, and local wisdom by utilizing surau was able to prevent radical Islamic ideology in West Sumatra. ${ }^{60}$

On the other hand, he criticized the ulama for dividing the ummah. He terms "ulama nan pamacah", which he describes as:

"Fatwanyo banyak nan ganjia, kajinyo banyak nan baru, pamacah urang sakampuang, pancarai anak jo bapak, pamutuih silaturrahmi, panghasuang malawan guru, danga nagari lah kusuik, sabab marampas karajo urang, naik mimbar jadi khatib, tidak siapo nan manyuruah, sadang wak nyo balum khatibnyo, sampai manyusah pamarintah"

(Many of his fatwas are strange, many of his studies are new, breaking the relationship in society, separating children and fathers, breaking friendship, provoking against teachers, society becomes tangled, because he takes people's jobs, delivers sermons even though they are not yet in their capacity, and their existence makes it difficult for the government). ${ }^{61}$

Teacher competence greatly affects the quality of graduates. Teachers who have a radical understanding or who like to divide unions will produce radical students as well. This is what Shaykh Sulaiman Arrasuli criticized. Therefore, it takes a teacher with the character of "ulama matahari" with deep understanding, to be an example, and to enlighten the people. As mentioned by Abdul Munip, one of the efforts to ward off religious radicalism in educational institutions is the importance of equipping teachers with a broad and cross-sectional understanding so that they are able to fulfill the

${ }^{59}$ Syekh Sulaiman Arrasuli, Pedoman Hidoep Di Alam Minangkabau Nasihat Siti Boediman Menoeroet Garisan Adat Dan Syara' (Bukittinggi: Tsamaratoel Ichwan, 1930), 60 .

${ }^{60}$ Sefriyono and Mukhibat, "Preventing Religious Radicalism Based on Local Wisdom: Interrelation of Tarekat, Adat, and Local Authority in Padang Pariaman, West Sumatera, Indonesia," SOSIOHUMANIKA: Jurnal Pendidikan Sains Sosial Dan Kemanusiaan 11, no. 1 (2018): 1-18.

${ }^{61}$ Arrasuli, Pedoman Hidoep Di Alam Minangkabau Nasihat Siti Boediman Menoeroet Garisan Adat Dan Syara'. 
spiritual thirst of students with enlightenment based on the peace and goodness of Islam. ${ }^{62}$

Second, cooperation between the government and scholars. Shaykh Sulaiman also emphasized the importance of scholars collaborating with the umara (government). He wrote:

"Apo pangajian nan maraso, nan balum biaso diamalkan, balum tapakai di nagari, elok panghulu malalukan, ulama tingga bafatwa, bunyi pepatah Minangkabau, syarak mangato adat mamakai"

(if there are Islamic teachings that are not usually practiced by the community, they have not been implemented in the nagari, let the leaders or the government implement them, while the ulama give a fatwa; this is in accordance with the Minangkabau proverb: Syarak mangato adat mamakai). ${ }^{63}$

He described the relationship between the cleric and the umara in the sentence: "The two people are for example people who sail the ship. One person is guarding the bow and the other is guarding the steering wheel, if both are in agreement, the voyage will arrive and the passenger will be safe, and if the two disagree then the cruise will not be successful and the passenger will have an accident" ${ }^{64}$

Thus, teachers with ulamaic characteristics must teach Islam that is rahmatan lil'alamin, based on the Quran and Hadith so that there is no radicalization and liberalization process in religion. On the other hand, the government is also expected to produce policies that are relevant to what is taught by teachers so that the community led is in safety, avoiding chaos. As in Ali Muhtarom's research, which states that there are at least five roles of ulama in counteracting religious radicalism, namely guiding the ummah, conveying messages of security and public order and partnering with the government. ${ }^{65}$

${ }^{62}$ Abdul Munip, "Menangkal Radikalisme Agama Di Sekolah," Jurnal Pendidikan Islam 1, no. 2 (2012): 159-81.

${ }^{63}$ Arrasuli, Pedoman Hidoep Di Alam Minangkabau Nasihat Siti Boediman Menoeroet Garisan Adat Dan Syara', 30-31.

${ }^{64}$ Syekh Sulaiman Arrasuli, Asal Pangkat Penghulu Dan Pendiriannya (Fort de Kock: Mathba'ah Islamiyah, 1927).

${ }^{65}$ Ali Muhtarom, "Peran Ulama Dalam Menangkal Radikalismeagama Di Kabupaten Batang Jawa Tengah," Ristek: Jurnal Riset, Inovasi Dan Teknologi Kabupaten Batang 1, no. 1 (2016): 45-65. 
Deradicalization of education in schools also requires collaboration between government, schools, teachers and families. ${ }^{66}$

Third, the morals of students who are religious and cultured. In the book Guidelines for Living in the Minangkabau Nature, Shaykh Sulaiman tells the story of Siti Budiman who gave messages to his son Muhammad Arif and daughter Siti Arifah. Through this story, Shaykh Sulaiman outlines educational messages, especially in shaping the morals of students: Muhammad Arif and Siti Arifah. One of the important messages to students is:

"Sungguah pun anak basekolah, salamo nyawo di kanduang badan, agamo jangan anak gadaikan, adat jangan anak jual, kepandaian buliah kito cari, asal manfaat pado kito."

(Even though you are educated, as long as you are alive, don't sell your religion, don't sell your customs, study knowledge that is beneficial to society). ${ }^{67}$ This message expressly wants students who are obedient to religious teachings while maintaining customs and culture. As stated above, obedience to religion and behave in accordance with Minangkabau customs and culture, will form a tolerant and moderate personality. Shaykh Solomon's message about religious and cultured personalities was also emphasized on students.

Therefore, students must study with the intention of getting the pleasure of Allah. With that intention, during their study, students must be oriented to the afterlife. He wrote,

"Apo ilmu nan lah dapek barang pangajian nan lah matang taraso, dipakai diamalkan ka bekal pulang ka akhirat, jangan sangajo untuak dunia, tuah pangkat, uang jo pitih, sakali jangan itu anak."

${ }^{66}$ A Jauhar Fuad, "Pembelajaran Toleransi: Upaya Guru Pendidikan Agama Islam Dalam Menangkal Paham Radikal Di Sekolah," in Proceedings of Annual Conference for Muslim Scholars, 2018, 561-71; Vicente Llorent-Bedmar, Verónica C CobanoDelgado Palma, and María Navarro-Granados, "Islamic Religion Teacher Training in Spain: Implications for Preventing Islamic-Inspired Violent Radicalism," Teaching and Teacher Education 95 (2020): 103138. https://doi.org/10.1016/j.tate.2020.103138

${ }^{67}$ Arrasuli, Pedoman Hidoep Di Alam Minangkabau Nasihat Siti Boediman Menoeroet Garisan Adat Dan Syara', 22. 
(All knowledge that has been mastered must be practiced as a provision for life in the hereafter, do not use that knowledge only for the world, or for the sake of rank, position, and wealth.). ${ }^{68}$

So, deradicalization of education is also important to do by affirming the intention of students in pursuing knowledge only because of Allah alone, oriented to the hereafter, not to gain position and wealth as world jewelry, so that religious teachings should be. Nanang Hasan Susanto emphasized that religious radicalism needs to be countered by implementing substantive Islamic education. One way is to live a religious life with Hanif, which is to live a religious life with an upright, sincere and passionate attitude. ${ }^{69}$

Fourth, educational material. Shaykh Sulaiman al-Rasuli views that the most important educational material is sciences that are oriented towards tafaqquh fi al-din. Such knowledge should be based on the motivation of belief in Allah so that sincerity appears because of Allah alone. ${ }^{70}$ Even so, he did not reject sciences in the general category, but he criticized people who were busy studying the world but did not know the science of religion. According to him, the development of religious knowledge was decreasing over time. Unlike the case with general science which is increasingly developing, especially the association with foreign cultures which many things contradict religious teachings. However, it is difficult to give birth to mujtahid in the religious field, because the light of the prophecy is getting darker and darker. ${ }^{71}$

Therefore, the study of religious knowledge is a priority. Among the educational materials that must be studied, it can be classified into six, namely: 1) Al-Qur'ān and Hadith; it must be supported by other sciences, including: Arabic language science which has twelve branches, Ushul Science, Al-Qur'ān Science, Hadith Science; and

${ }^{68}$ Arrasuli.

${ }^{69}$ Nanang Hasan Susanto, "Menangkal Radikalisme Atas Nama Agama Melalui Pendidikan Islam Substantif," Nadwa: Jurnal Pendidikan Islam 12, no. 1 (2018): 6588.

${ }^{70}$ Arrasuli, Pedoman Hidoep Di Alam Minangkabau Nasihat Siti Boediman Menoeroet Garisan Adat Dan Syara', 26.

${ }^{71}$ Syekh Sulaiman Arrasuli, Al-Jawāhir Al-Kalāmiyah Fi Bayān 'Aqā'Id Alİmāniyah (Fort de Kock: Drukkerij Islamijah FDK, 1927), 57. 
tool sciences in berijtihad; 2) Arabic as a science tool; 3) Aqidah/ Tauhid; 4) Fiqh; 5) Akhlak; and 6) Skills. ${ }^{72}$

$\mathrm{He}$ also applied these materials at MTI Canduang. The madrasah he founded was more oriented to the study of tafaqquh $f i$ al-din, of course with the style of Ahl al-Sunnah wa al-Jamā'ah wa Syafi'iyyah. Although students are educated to hold a firm stand on ASWAJASI, they are also taught the comparison of schools of thought through the Bidāyah al-Mujtahid book which contains four schools of Ibn Rushd's work for grade VII at MTI Canduang. With material enrichment like this, MTI Canduang graduates become scholars who are firm in their stance but can respect differences in mazhab so that they have moderate attitudes. ${ }^{73}$

With a more focused and complete understanding of Islamic studies, it is hoped that students will master the Islamic religious sciences more comprehensively. He also emphasized the importance of mastering knowledge in its entirety, mastering books that are studied thoroughly from beginning to end, understand general and specific rules, put the arguments in their place, not to change the meaning. ${ }^{74}$ This is very important in preventing religious radicalism. ${ }^{75}$ This is because a narrow and shallow understanding of religious teachings has the potential to generate radical thoughts in religion. ${ }^{76}$

Fifth, the method of educating. In educating, the teacher should prioritize compassion, be fair in front of his students, treat students like real children, and teach them sincerely. ${ }^{77}$ This is relevant to the concept of education without violence. Violent education can also result in a child's soul becoming harder, more violent, and emotionally prone, which can lead to extreme and radical actions. Imam Machali

${ }^{72}$ Arrasuli, Pedoman Hidoep Di Alam Minangkabau Nasihat Siti Boediman Menoeroet Garisan Adat Dan Syara', 29-30.

${ }^{73}$ Kosim, Gagasan Syekh Sulaiman Al-Rasuli Tentang Pendidikan Islam Dan Penerapannya Pada Madrasah Tarbiyah Islamiyah Di Sumatera Barat, 404.

${ }^{74}$ Arrasuli, Pedoman Hidoep Di Alam Minangkabau Nasihat Siti Boediman Menoeroet Garisan Adat Dan Syara'.

${ }^{75}$ Leonie Schmidt, "Aesthetics of Authority:'Islam Nusantara'and Islamic 'Radicalism' in Indonesian Film and Social Media,' Religion, 2021, 1-22. https://doi. org/10.1080/0048721X.2020.1868387.

${ }^{76}$ Qardhawi, Islam Ekstrem: Analisis Dan Pemecahannya.

77 Arrasuli, Pedoman Hidoep Di Alam Minangkabau Nasihat Siti Boediman Menoeroet Garisan Adat Dan Syara', 31. 
said that peace education is one of the efforts to deradicalize religion, among the indicators is full of peace and non-violence. ${ }^{78}$

From the thoughts of Shaykh Sulaiman Arrasuli above, it can be understood that his idea of education has relevance to efforts to deradicalize education. The strengthening of religion and local wisdom of Minangkabau culture is a distinctive thought of Shaykh Sulaiman and is influential in the lives of Muslims, especially Islamic groups with the ideology of Ahl al-Sunnah Wa al-Jamā'ah wa Syafi'iyah which until now dominate Minangkabau society. Religious ideas like this seem to have influenced the Minangkabau people, whose characteristics of immigrants continue to exist and are accepted by many people in their overseas areas. Of course, Shaykh Sulaiman Arrasuli's thoughts and efforts to produce ASWAJASIbased scholars through the MTI that he founded have also contributed. Therefore, the efforts to deradicalise education discussed in this article are expected to be a model and inspiration in counteracting religious radicalism through education.

\section{CONCLUSIONS}

Shaykh Sulaiman actually gave birth to thoughts that were relevant to the concept of deradicalization. Shaykh Sulaiman puts forward religious education with the concept of Ahl al-Sunnah wa alJamā'ah wa Syafi'iyah because it is proven to contain tolerant and balanced teachings and attitudes that are widely adopted by people in Indonesia, including in Minangkabau. This religious understanding also accommodates local wisdom that grows in the midst of society, namely Minangkabau customs and culture which are also full of democratic values, equality, equality, and openness.

The concept of education based on religion and local Minangkabau wisdom is one of the models in the development of educational deradicalisation. At least, history proves that Shaykh Sulaiman Arrasuli appeared as a traditional Islamic figure who was accepted by many circles and scholars who were born from the educational institution he founded (Madrasah Tarbiyah Islamiyah Canduang) were known as ulama who were firm in their opinion but still respecting differences.

${ }^{78}$ Imam Machali, "Peace Education Dan Deradikalisasi Agama," Jurnal Pendidikan Islam 2, no. 1 (2013): 41-64. 


\section{REFERENCES}

Abbas, Siradjuddin. Sejarah Dan Keagungan Madzhab Syafi'i. Jakarta: Pustaka Tarbiyah Baru, 2010.

Alaiddin Koto; Mafri Umar; Abdul Halim. Sejarah Perjuangan Persatuan Tarbiyah Islamiyah Di Pentas Nasional. Jakarta: Tarbuyah Press, 2006.

Alam, Masnur. "A Collaborative Action in the Implementation of Moderate Islamic Education to Counter Radicalism." International Journal of Innovation, Creativity and Change 11 (2020).

Aldomi, Hasan Zaini; Muhammad Kosim; Prinsip Dan Jati Diri Persatuan Tarbiyah Islamiyah. Padang: Jasa Surya, 2015.

Amrin, Rina. "Pemikiran Hukum Islam Syekh Sulaiman Al-Rasuli Dan Syekh Ibrahim Musa (Tesis)." Pascasarjana IAIN Imam Bonjol Padang, 2011.

Arrasuli, Syekh Sulaiman. Al-Jawāhir Al-Kalāmiyah Fi Bayān 'Aqā 'Id Al-İmāniyah. Fort de Kock: Drukkerij Islamijah FDK, 1927.

—. Asal Pangkat Penghulu Dan Pendiriannya. Fort de Kock: Mathba'ah Islamiyah, 1927.

. "Keadaan Minangkabau Dahulu Dan Sekarang." Majalah Al-Mizan. Maninjau, 1938.

_. "Mari Bersatu Dengan Adat Dan Syarak (Harian Haluan) Q.”April 1951.

- Pedoman Hidoep Di Alam Minangkabau Nasihat Siti Boediman Menoeroet Garisan Adat Dan Syara'. Bukittinggi: Tsamaratoel Ichwan, 1930.

—. Tabligh Al-Amānah. Bukittinggi: t.p., 1954.

Asnan, Gusti. Kamus Sejarah Minangkabau. Padang: Pusat Pengkajian Islam dan Minangkabau (PPIM), 2003, 2003.

Awaluddin, Asep. “URGENSI AHLU SUNNAH WAL JAMA'AH DAN PENDIDIKAN KEBANGSAAN (Tinjauan Atas Qonun 
Assasy Ahlu Sunnah Wal Jama'ah Karya Rois Akbar Nahdlatul Ulama KH. Hasyim Asy'ari).” Muslim Heritage 5, no. 2 (2020): 344.

Azra, Azyumardi. “Kembali Ke Jati Diri (2)." Republika. November 2016. https://republika.co.id/berita/kolom/resonansi/16/11/23/ oh3nmo319-kembali-ke-jati-diri-2.

Bagindo, Farhan Muin Dt. "Pokok-Pokok Ajaran Adat Minangkabau, Adat Basandi Syarak, Syarak Basandi Kitabullah Beserta Penjelasannya Dan Berlaku Untuk Seluruh Wilayah Minangkabau." In Mambangkik Batang Tarandam Minangkabau Di Tapi Jurang, edited by AL Bazar M Arif. Jakarta: YPMUI, 2013.

Bruinessen, Martin van. Tarekat Naqsyabandiyah Di Indonesia. Bandung: Mizan, 1992.

Chaniago, Hasril. 101 Orang Minang Di Pentas Sejarah. Padang: Yayasan Citra Budaya Indonesia, 2010.

Famela, Jely Agri. "Pro Dan Kontra Pelaksanaan Program Deradikalisasi Badan Nasional Penanggulangan Teroris (BNPT).” FISIP UI, 2013.

Feriyanto, Feriyanto. "Tarekat Dan Moderasi Beragama." Tatar Pasundan: Jurnal Diklat Keagamaan 14, no. 2 (2020): 158-72.

Fuad, A Jauhar. "Pembelajaran Toleransi: Upaya Guru Pendidikan Agama Islam Dalam Menangkal Paham Radikal Di Sekolah." In Proceedings of Annual Conference for Muslim Scholars, 561-71, 2018.

Hikam, Muhammad A S. Deradikalisasi: Peran Masyarakat Sipil Indonesia Membendung Radikalisme. Penerbit Buku Kompas, 2016.

Huda, Mualimul. "Eksistensi Pesantren Dan Deradikalisasi Pendidikan Islam Di Indonesia.” Jurnal Kajian Keislaman Dan Kemasyarakatan 3, no. 1 (2018): 91.

http://www.politik.lipi.go.id/kolom/kolom-1/tinjauan-buku/1230tinjauan-buku-membumikan-deradikalisasi 
Ismayilov, Murad. "Islamic Radicalism That Never Was: Islamic Discourse as an Extension of the Elite's Quest for Legitimation. Azerbaijan in Focus." Journal of Eurasian Studies 10, no. 2 (2019): 183-96.

Isnawan, Fuadi. "Program Deradikalisasi Radikalisme Dan Terorisme Melalui Nilai-Nilai Luhur Pancasila." FIKRI: Jurnal Kajian Agama, Sosial Dan Budaya 3, no. 1 (2018): 1-28.

Karwadi. "Deradikalisasi Pemahaman Ajaran Islam." Al-Tahrir: Jurnal Pemikiran Islam 14, no. 1 (2014): 139-56.

Khatib, Syamsul Bahri. Tarekat Abd Al-Rauf Singkel Dalam Tanbih Al-Masyi. Padang: Hayfa Press, 2012.

Kosim, Muhammad. "Gagasan Syekh Sulaiman Al-Rasuli Tentang Pendidikan Islam Dan Penerapannya Pada Madrasah Tarbiyah Islamiyah Di Sumatera Barat”. Disertasi, Pascasarjana IAIN Imam Bonjol Padang, Padang, 2013.

—. "Syekh Sulaiman Al-Rasuli Tokoh Pendidikan Islam Bercorak Kultural." Turast: Jurnal Penelitian Dan Pengabdian 3, no. 1 (2015): 23-41.

_ "Tradisi Madrasah Tarbiyah Islamiyah Di Sumatera Barat" IV, no. 1 (2013): 21-45.

Koto, Alaiddin. Persatuan Tarbiyah Islamiyah: Sejarah, Paham Keagamaan, Dan Pemikiran Politik 1945-1970. Jakarta: RajaGrafindo Persada, 2012.

Latif, Sanusi. "Gerakan Kaum Tua Di Minangkabau (Disertasi)." IAIN Syarif Hidayatullah Jakarta, 1988.

Llorent-Bedmar, Vicente, Verónica C Cobano-Delgado Palma, and María Navarro-Granados. "Islamic Religion Teacher Training in Spain: Implications for Preventing Islamic-Inspired Violent Radicalism." Teaching and Teacher Education 95 (2020): 103138.

Machali, Imam. "Peace Education Dan Deradikalisasi Agama." Jurnal Pendidikan Islam 2, no. 1 (2013): 41-64. 
Mahmudi. "Islam Moderat Sebagai Penangkal Radikalisme." In Proceedings of Annual Conference for Muslim Scholars, 82-91, 2018.

Masduqi, Irwan. "Deradikalisasi Pendidikan Islam Berbasis Khazanah Pesantren.” Jurnal Pendidikan Islam 2, no. 1 (2013): $1-20$.

Muhtarom, Ali. "Peran Ulama Dalam Menangkal Radikalismeagama Di Kabupaten Batang Jawa Tengah." Ristek: Jurnal Riset, Inovasi Dan Teknologi Kabupaten Batang 1, no. 1 (2016): 4565 .

Mukhibat. "Deradikalisasi Dan Integrasi Nilai-Nilai Pluralitas Dalam Kurikulum Pesantren Salafi Haraki Di Indonesia." AlTahrir: Jurnal Pemikiran Islam 14, no. 1 (2014): 181-204.

. "Re-Edukasi Dan Re-Motivasi TerhadapPelakuRadikalisme Dan Terorisme: Membangun Kesadaran Keagamaan Yang Inklusif Dan Humanis Di Indonesia." SOSIOHUMANIKA 7, no. 1 (2014).

Munip, Abdul. "Menangkal Radikalisme Agama Di Sekolah." Jurnal Pendidikan Islam 1, no. 2 (2012): 159-81.

Munir, Miswar. "Nilai-Nilai Pendidikan Dalam Petatah Petitih Adat Minangkabau (Alternatif Membangun Pendidikan Berkarakter)." Al Hurriyah: Jurnal Hukum Islam 14, no. 1 (2018): 95-104.

Muqoyyidin, Andik Wahyun. "Membangun Kesadaran Inklusifmultikultural Untuk Deradikalisasi Pendidikan Islam." Jurnal Pendidikan Islam 2, no. 1 (2013): 131-51.

_ . "Membumikan Deradikalisasi Pendidikan Islam Sebagai Respons AntisipatifRadikalisme Di Era Global." In Proceedings of Annual Conference for Muslim Scholars, 504-12, 2017.

Musyarrofah, Mifrohatul. "Deradikalisasi Melalui Pendidikan Karakter Berbasis Khazanah Pesantren." Jurnal MUDARRISUNA: Media Kajian Pendidikan Agama Islam 8, no. 1 (2018): 46-59. 
Nugraha, Muhamad Tisna. "Fundamentalisme Pendidikan Agama Di Jejaring Sosial." Al-Tahrir: Jurnal Pemikiran Islam 18, no. 1 (2018): 41-62.

Prasetiawati, Eka. "Menanamkan Islam Moderat Untuk Menanggulangi Radikalisme Di Indonesia." Fikri: Jurnal Kajian Agama, Sosial Dan Budaya 2, no. 2 (2017): 523-70.

Purippendolf, Klans. Analisis Isi: Pengantar Teori Dan Metodologi. Jakarta: Rajawali Press, 1991.

Qardhawi, Yusuf. "Islam Ekstrem: Analisis Dan Pemecahannya, Terj." Alwi AM. Bandung: Mizan, 1991.

Ramadhan, Muammar. "Deradikalisasi Agama Melalui Pendidikan Multikultural Dan Inklusivisme (Studi Pada Pesantren AlHikmah Benda Sirampog Brebes)." Jurnal SMART (Studi Masyarakat, Religi, Dan Tradisi) 1, no. 2 (2015).

Rohmah, Anny Nailatur, and Ashif Az Zafi. "Jejak Eksistensi Mazhab Syafii Di Indonesia." Tamaddun: Jurnal Sejarah Dan Kebudayaan Islam 8, no. 1 (2020).

Sahid, Mualimin Mochammad, Ahmad Nur Jihadi, and Setiyawan Gunardi. "Moderate Islam As A Solution To Pluralism In The Islamic World: The Experience Of Indonesia." Al-Shajarah: Journal of the International Institute of Islamic Thought and Civilization (ISTAC), 2019, 1-24.

Saleh, Khairul, and Muhammad Arbain. "Deradikalisasi Di Perguruan Tinggi: Strategi Menangkal Radikalisme Melalui Pendidikan Islam.” Ar-Ruzz Media, 2019.

Sanusi, Ahmad. "Pemikiran Ushul Fiqh Imam Syafi'i." Syakhsia: Jurnal Hukum Perdata Islam 19, no. 2 (2018): 223-44.

Sarwan, Mansoureh Ebrahimi, and Kamaruzaman Yusoff. "AL-IMAM MAGAZINE (1906-1908): THE STUDY OF KAUM MUDA'S THOUGHT ON ISLAMIC EDUCATION RENEWAL IN SOUTHEAST ASIA." Journal of Critical Reviews 7, no. 11 (2020): 499-503. 
Schmidt, Leonie. "Aesthetics of Authority:'Islam Nusantara' and Islamic 'Radicalism'in Indonesian Film and Social Media." Religion, 2021, 1-22.

Sefriyono and Mukhibat. "Preventing Religious Radicalism Based on Local Wisdom: Interrelation of Tarekat, Adat, and Local Authority in Padang Pariaman, West Sumatera, Indonesia." SOSIOHUMANIKA: Jurnal Pendidikan Sains Sosial Dan Kemanusiaan 11, no. 1 (2018): 1-18.

Shihab, M Quraish. Islam Yang Saya Pahami: Keragaman Itu Rahmat. Lentera Hati Group, 2018.

Steenbrink, Karel A. Pesantren, Madrasah, Sekolah: Pendidikan Islam Dalam Kurun Moderen, . Jakarta: LP3ES, 1994.

Suprapto, Rohmat. "Deradikalisasi Agama Melalui Pendidikan Multikultural-Inklusiv (Studi Pada Pesantren Imam Syuhodo Sukoharjo)." Profetika: Jurnal Studi Islam 15, no. 02 (2016): 246-60.

Suprayogo, Imam, and Tobroni. Metodologi Penelitian SosialAgama. Remaja Rosdakarya, 2001.

Susanto, Nanang Hasan. "Menangkal Radikalisme Atas Nama Agama Melalui Pendidikan Islam Substantif." Nadwa: Jurnal Pendidikan Islam 12, no. 1 (2018): 65-88.

Susilo, Sulistiyono, and Reza Pahlevi Dalimunthe. "Moderate Southeast Asian Islamic Education as a Parent Culture in Deradicalization: Urgencies, Strategies, and Challenges." Religions 10, no. 1 (2019): 45.

Suyanto, Bagong. Metode Penelitian Sosial: Berbagai Alternatif Pendekatan. Prenada Media, 2015.

Wahyudin, Didin. "Pendidikan Aswaja Sebagai Upaya Menangkal Radikalisme." Dinamika Penelitian: Media Komunikasi Penelitian Sosial Keagamaan 17, no. 2 (2017): 291-314.

Yunus, Yulizal. "Aspek-Aspek Pendidikan Islam Dalam Sastra Ulama Minangkabau; Studi Syair Syekh Sulaiman Al-Rasuli (Disertasi).” Pascasarjana UIN Imam Bonjol Padang, 2018. 
Zulkifli. "Syekh Sulaiman Al-Rasuli; Upaya Pembaharuan Pendidikan Islam Di Minangkabau (Tesis).” Pascasarjana IAIN Imam Bonjol Padang, 2010. 